\title{
WIKTOR KULERSKI
}

(D) http://orcid.org/0000-0003-1357-8445

\section{Pewien wieczór jesienny}

Rodzina Winogórów mieszkała w Międzylesiu przy ulicy Głównej 15. Budynek należał do Kazimierza Sucheckiego, cieśli ogłaszającego się w miejscowym miesięczniku „Na Straży” następująco: „Przedsiębiorstwo budowy domów z własnych i powierzonych materiałów K. Suchecki = Międzylesie pod Warszawą"1. Majer Chaim Winogóra z żoną Taubą prowadzili tam także sklep spożywczy. Mieli czwórkę dzieci: Jakuba (1918), Jankiela (1920), Esterę (1925) i Rywkę (1928)². Estera i Rywka przyjaźniły się z dziećmi Karola i Sabiny Mrozińskich mieszkających przy ulicy Głównej 28, róg ulicy 11 Listopada, na piętrze nad restauracją A. Zaczewskiego. Karol Mroziński był tokarzem frezerem zatrudnionym w pobliskiej Fabryce Aparatów Elektrycznych Kazimierza Szpotańskiego. Mrozińscy dzieci mieli również czworo: Józka (1930), Alicję (1931), Krystynę (1935) i Michała (1937) ${ }^{3}$.

31 października 1940 roku w nieodległej Falenicy utworzono getto. Przesiedlenia miały być zakończone do 1 grudnia. Wówczas to Winogórowie musieli opuścić Międzylesie. 10 czerwca 1941 roku Żydowska Gmina w Falenicy wysłała telegram do centrali Żydowskiej Samopomocy Społecznej w Krakowie: „Ludzie puchną z głodu i umierają. Konieczna natychmiastowa pomoc. Kuchnia nieczynna. Przeszło 3 tysiące głodnych"4. Winogórowie korzystali z pomocy Mrozińskich. Esterka i Rywka wieczorami wymykały się z getta i po zaopatrzeniu w żywność u przyjaciół w Międzylesiu wracały. Wydostanie się z falenickiego getta nie było zbyt trudne, szczególnie od strony lasu, w pobliżu północnej granicy dzielnicy zamkniętej. Tam stanowił ją drut kolczasty dosyć niedbale rozpięty

${ }^{1}$ „Na Straży” 1937, nr 5, lipiec-sierpień, s. 17 (nienumerowana).

${ }^{2}$ Księga ocen z roku szkolnego 1939/40 i wcześniejsze. Archiwum Szkoły Podstawowej nr 138 im. Józefa Horsta w Warszawie.

${ }^{3}$ Dane dotyczące rodziny Mrozińskich według relacji Karola, Sabiny i Ewy Mrozińskich. Archiwum własne.

${ }^{4}$ Cyt. za: J. Dobrzyńska: Falenica moja miłość po raz drugi. Wyd. 2. Warszawa 1996, s. 118. 
na drewnianych palach. Blisko przebiegała też najkrótsza droga do Międzylesia, licząca zaledwie około $6 \mathrm{~km}$. Był to dawny Trakt Wołowy, w czasach najnowszych nazwany Napoleońskim. Trakt prowadził wzdłuż północno-wschodnich obrzeży Miedzeszyna i Radości, po czym wiódł przez las Branickich oddzielający Radość od Międzylesia, by przyjąć nazwę ulicy 11 Listopada i tam przeciąć ulicę Jasną. Do Głównej pozostawało już zaledwie paręset metrów. Przed wyjściem z lasu Winogórzanki prawdopodobnie schodziły z Traktu, by bocznymi ścieżkami obejść od południa znajdującą się u jego wylotu leśniczówkę Stanisława Bałabana, w której trzymano psy. Na domiar złego przy ulicy 11 Listopada 6, róg Jasnej, mieszkał współpracujący z okupantem administrator nieruchomości żydowskich Stefan Poleszczuk ${ }^{5}$. Bezpieczniej było zatem ominąć te miejsca i wyjść w kierunku domu Mrozińskich blisko skrzyżowania z ulicą Główną.

Las Branickich był to sosnowo-dębowy bór z domieszką brzozy, topoli osiki, obu gatunków czeremchy oraz z pojedynczymi świerkami i grabami. Zarówno od strony Międzylesia, jak i od Radości wzdłuż ściany lasu posadzono przeciwogniowe szpalery brzóz, przy czym w Radości na skraju nieznaczonego zagłębienia gruntu uchowało się parę zapóźnionych olch. W Międzylesiu do skraju lasu, na południe od Traktu, przylegało odkryte niczyje przylesie. Porastała je roślinność charakterystyczna dla suchych powydmowych międzyleskich piasków - macierzanka, rozchodnik, kępy szczotlichy i kostrzewy, jastrzębiec, miejscami kocanki i wilczomlecz. Górowały z rzadka rozsiane większe i mniejsze jałowce różnego wieku i przerozmaitego pokroju. Na północ od Traktu było inaczej - początkowo bezpośrednio z lasem graniczyły parcele $\mathrm{z}$ zabudową, a dalej, w miarę bliskości rowów odwadniających w okolicy sąsiedniej Wiśniowej Góry, teren stawał się mniej wysuszony.

To południowe, odkryte i niczyje przylesie było miejscem, przez które wielokrotnie musiały przechodzić Esterka i Rywka Winogórzanki, trzymając się z dala od leśniczówki i domu Poleszczuka. Któregoś wieczoru prawdopodobnie natknęły się tam na Juliusza Krzyżewskiego i Jeremiego Przyborę. Wspomnienie tego spotkania najwidoczniej nie opuszczało Krzyżewskiego, powracało niczym ta "myśl natrętna”, skoro po upływie półtora roku w wierszu Idée fixe właśnie, dedykowanym Przyborze, pisał:

Czy pamiętasz, mój drogi Jeremi, pewien wieczór jesienny, gdy razem leżeliśmy pod lasem, do ziemi tuląc piersi rozgrzane i twarze?

Macierzanka pachniała i mięta, a jałowiec jak krzew mojżeszowy

${ }^{5}$ Centralne Archiwum KC PZPR. Dokumenty Kedywu Obszaru Warszawskiego, sygn. 203/ X-61 mf 2139/2. 
strzelał ogniem i dymem, pamiętasz,

dłonie nasze złocący i głowy?

Powiedziałem ci wtedy, że las ten jest jak Morze Czerwone, którędy idą Żydzi, jak drzewa liściaste pośród sosen i świerków uwiędłe.

Przodem Mojżesz niby dąb omszały niosąc czoło w koronie rozwianej, lasu fale strącał pastorałem, upiętrzone pod wiatr jak organy.

Dalej brzozy w koszulach ofiarnych i gromada olch brzydkich i chromych, a ze świerków wiatr zgarniał fontanny piany w blasku od nieba czerwonej.

Zapytałeś mnie wtedy, Jeremi, nie bez smutku i nie bez ironii, czy proroctwa w fantazji mej nie ma i kto nam je, jeśli jest, odsłoni?

I mówiłeś mi jeszcze, pamiętasz, że las przejdą i nic się nie stanie stare dęby i młode Żydzięta na tej ziemi nie im obiecanej.

Miałeś rację, niestety, mój drogi; dziś pod lasem z tej i z tamtej strony stoją w łodziach piaszczystych załogi brzóz Jehowie bijących pokłony. ${ }^{6}$

Wiersz jest datowany: „Międzylesie 5 II 1943”. Czas wydarzenia można określić względnie dokładnie. Była to pora zachodu słońca („blask od nieba czerwony”), wrzesień (macierzanka jeszcze kwitnie) w 1941 roku. Nie mógł to być rok 1942, jako że getto falenickie przestało istnieć 20 sierpnia tegoż roku, ani 1940, ponieważ utworzono je wtedy 31 października. W 1941 roku panował tam głód. Esterka i Rywka musiały często wędrować z Falenicy do Międzylesia i z powrotem. Możliwe zresztą, że nie były same - co najmniej dziesięć międzyleskich rodzin przebywało w getcie falenickim. Niewykluczone, że nie tylko Winogórowie próbowali szukać pomocy u niedawnych sąsiadów, choć obecnie brzmi to

${ }^{6}$ J. Krzyżewski: Poezje. Wybrał i oprac. P. Mitzner. Wstęp J. Iwaszkiewicz. Warszawa 1978, s. 201-202. 
gorzko i mało prawdopodobnie. Potwierdzenie takiego wsparcia mamy jednak tylko od Karola i Sabiny Mrozińskich7, którzy udzielali go Esterce i Rywce Winogórzankom (jeśli nie liczyć pomocy osobom, które getta uniknęły lub z niego zbiegły). Jest prawdopodobne, iż obietnica Przybory, „że las przejdą i nic się nie stanie", dotyczy Estery i Rywki. Jeśli tak, to zapewne wracały wtedy z żywnością od Mrozińskich i wchodziły do lasu. Wrażenie, jakie na Krzyżewskim wywarły „młode Żydzięta”, musiało być dojmujące, choć widział je o zachodzie i chyba z daleka. Można przypuszczać przy tym, że starały się pozostać niezauważone, umknąć czym prędzej z pola widzenia dwóch obcych leżących przy płonącym jałowcu. Aby dojść do Mrozińskich, za każdym razem musiały przechodzić obok niezabudowanej parceli przy ulicy 11 Listopada. Tam, pod krzywą sosną, zabijano Żydów złapanych w Międzylesiu i okolicy. Tam został doprowadzony oraz zastrzelony rówieśnik Esterki i sąsiad Moszek Centner, syn Hersza, szewca, który to miał pracownię i mieszkał przy ulicy Głównej 22, naprzeciwko Winogórów. A schwytał go i oddał w ręce policji stróż Jan Orlicki ${ }^{8}$. Juliusz Krzyżewski roi o przejściu przez Zagładę jak niegdyś przez Morze Czerwone. Przybora trzeźwo ocenia to, czego są świadkami. Nie ma złudzeń. W wierszu podważa wizję ocalenia, wątpi. Krzyżewski przypisuje mu smutek i ironię. Wtedy Przybora stara się oszczędzić przyjaciela. Łagodzi opinię, jednak tylko w odniesieniu do jednostkowego wydarzenia - „las przejdą i nic się nie stanie”. Po półtora roku Krzyżewski wraca do pierwszej oceny Przybory - „miałeś rację, niestety, mój drogi” - i pisze o „brzozach w koszulach ofiarnych”. Zapis jest dramatyczny. "Żydziąt” już nie ma. Z tła występują statyści i przyjmują role nieobecnych aktorów - „stoją w łodziach piaszczystych załogi / brzóz Jehowie bijących pokłony”. Zagłada dokonała się.

Scenografia zarysowana przez Krzyżewskiego pozwala umiejscowić wydarzenie z dużą dokładnością, podobnie jak osadzone jest ono w czasie. Poza jednym odstępstwem od wierności opisu - „i mięta”. Tej rośliny, wilgociolubnej we wszystkich występujących u nas gatunkach, nie uświadczysz na przylesiu lasu Branickich, na południe od Traktu Wołowego. Co więcej, nie ma jej tam, gdzie rośnie sucholubna macierzanka, i odwrotnie - nie znajdziesz macierzanki tam, gdzie mięta. To wyjątkowe sprzeniewierzenie się realiom tłumaczyć można ustępstwem na rzecz literackiej formy, a może i potoczności. Poza tym wszystko się zgadza. Wówczas w lesie Branickich rosły nawet owe „stare dęby”. Do dziś po jednym tylko z nich pozostał powalony, ogromny i rozpadający się pień w pobliżu miejsca po spalonej leśniczówce. Ze szpalerów brzóz gdzieniegdzie zachowały się pojedyncze drzewa. Jałowce wytępiono, w znacznej części przez

\footnotetext{
${ }^{7}$ Notatka z rozmowy z Karolem i Sabiną Mrozińskimi w 1972 roku. Archiwum własne.

${ }^{8}$ Według relacji: Bogdana Podbielskiego (ur. 1927), Eugeniusza Klimontowicza (ur. 1927), Stanisława Maciejewskiego (ur. 1925), Janiny Michalik (ur. 1899), Karola Mrozińskiego (ur. 1905), Sabiny Mrozińskiej (ur. 1908) oraz Adama Czułowskiego (ur. 1892), ówczesnego właściciela domu przy ul. Głównej 22. Archiwum własne.
} 
podpalenia, jak to uczynili Krzyżewski z Przyborą, a i używając ich do wędzenia. Przylesie zarosło samosiejkami sosen. Dom Mrozińskich spłonął w 1944 roku, Esterka i Rywka zostały zabite w 1942, Juliusz Krzyżewski zginął w 1944, a Jeremi Przybora zmarł w 2004 roku.

W twórczości Juliusza Krzyżewskiego Idée fixe jest jedynym utworem, gdzie pojawia się wątek Zagłady, której poeta był świadkiem przez cztery lata.

Międzylesie, styczeń 2019 roku

P.S. Profesorowi Piotrowi Mitznerowi składam podziękowanie za zwrócenie mi uwagi na międzyleskie wiersze Juliusza Krzyżewskiego.

Wiktor Kulerski

\section{One Autumn Evening}

\section{Summary}

This article focuses on the writing process of Juliusz Krzyżewski's "Idée fixe" and the Shoah connotations of this poem. As it is shown in the text, the Winogórowie - a Jewish family - and the Mrozińscy - a Polish family - had been friends whose contact and mutual help did not cease when the Winogórowie were ghettoised in Falenica. It is argued that this situation was made possible by the forest separating Międzylesie from Falenica. In this forest, the poet, who later inscribed himself as a witness in "Idée fixe," met girls escaping from the ghetto. Not only does the author of this article ponder upon the question why Krzyżewski has left these events unmentioned for so many years, but also he attempts to present not just the poet, but the poetry as a witness.

Key words: forest, ghetto, Falenica, Międzylesie, Jeremi Przybora 